Вісник Дніпропетровського університету. Серія хімія

Bulletin of Dnipropetrovsk University. Series Chemistry

ISSN 2306-871X (Print),

ISSN 2313-4984 (Online)

journal homepage: http://chemistry.dnu.dp.ua

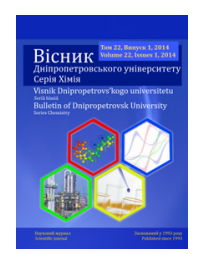

UDC 378.4(477.63)(092)+54(477.63)(092)

\author{
L. V. PISARZHEVSKY. THE FOUNDER OF CHEMICAL SCIENCE \\ AND EDUCATION IN DNIPROPETROVSK UNIVERSITY \\ Valerij S. Kovalenko, Viktor F. Vargaljuk, Nadiia V. Stets* \\ Oles Honchar Dnipropetrovsk National University, 72, Gagarin Ave., Dnipropetrovsk, 49010, Ukraine \\ Received 4 November 2013; revised 21 November 2013; accepted 2 December 2013
}

A b s tra c t

The article is devoted to the Lev Vladimirovich Pisarzhevsky's 140th birth anniversary, who was a distinguished chemical scientist, founder of the important area of chemical science - electronic chemistry. The article dwells upon the basic stages of the scientist's life and creative art. The major results of scientific and educational activity during Dnipropetrovsk period of his life are reported. His role in the foundation of dnipropetrovsk scientific school of physical chemistry, as well as in its establishment, is shown. The pioneering role of the academician L. V. Pisarzhevsky in the formation of the theory of redox reactions as processes of returning and joining of electrons, which is generally accepted nowadays, as well as in the creation of backgrounds of modern electronic theories of catalysis, has been shown. L. V. Pisarzhevsky is characterized as a wonderful lecturer and teacher who expounded chemical material from the point of view of electronic conception and laid the foundation for the reformation of chemistry. The role of the academician L. V. Pisarzhevsky in the foundation of Dnipropetrovsk University and its chemical department, as well as in the organization of educational process in this establishment, is exposed using archive materials, which are kept in the funds of the State Archive of the Dnipropetrovsk region and of the historical museum of Oles Honchar Dnipropetrovsk National University.

Keywords: L. V. Pisarzhevsky, electronic chemistry, theory of catalysis, Institute of physical chemistry, Dnipropetrovsk university.

\title{
АКАДЕМІК Л. В. ПИСАРЖЕВСЬКИЙ - ФУНДАТОР ХІМІЧНОЇ НАУКИ ТА ОСВІТИ В ДНІПРОПЕТРОВСЬКОМУ УНІВЕРСИТЕТІ
}

\author{
Валерій С. Коваленко, Віктор Ф. Варгалюк, Надія В. Стець*
}

Дніпропетровський національний університет імені Олеся Гончара,

А н о т а ц і я

просп. Гагаріна, 72, Дніпропетровськ, 49010, Україна

Статтю присвячено 140-річчю з дня народження академіка Лева Володимировича Писаржевського, видатного вченого-хіміка, основоположника важливого напряму науки - електронної хімії. Висвітлено основні етапи його життєвого та творчого шляху. Розкрито визначні результати наукової та педагогічної діяльності в дніпропетровський період життя вченого, його роль у створенні та становленні дніпропетровської наукової школи фізичної хімії. Описано новаторство академіка Л. В. Писаржевського у формуванні загальновизнаних нині уявлень про окисно-відновні реакції як процеси віддачі та приєднання електронів, а також основних засад сучасних електронних теорій каталізу. Розкрито участь академіка Л. В. Писаржевського у заснуванні Дніпропетровського університету і хімічного факультету та організації навчального процесу в цьому закладі.

Ключові слова: Л. В. Писаржевський, електронна хімія, теорія каталізу, Інститут фізичної хімії, Дніпропетровський університет.

\section{АКАДЕМИК Л. В. ПИСАРЖЕВСКИЙ - ОСНОВОПОЛОЖНИК ХИМИЧЕСКОЙ НАУКИ И ОБРАЗОВАНИЯ В ДНЕПРОПЕТРОВСКОМ УНИВЕРСИТЕТЕ}

\author{
Валерий С. Коваленко, Виктор Ф. Варгалюк, Надежда В. Стец* \\ Днепропетровский национальный университет имени Олеся Гончара, \\ просп. Гагарина, 72, Днепропетровск, 49010, Украина
}

А н н о т а ци я

Статья посвящена 140-летию со дня рождения академика Льва Владимировича Писаржевского, выдающегося ученого-химика, основоположника важного направления науки - электронной химии. Освещены основные этапы его жизненного и творческого пути. Раскрыты значительные результаты научной и педагогической деятельности в днепропетровский период жизни ученого, его роль в создании и становлении днепропетровской научной школы физической химии. Описано новаторство академика Л. В. Писаржевского в формировании общепризнанных сегодня представлений об окислительно-восстановительных реакциях как процессах отдачи и присоединения электронов, а также оснований современных электронных теорий катализа. Раскрыта роль академика Л. В. Писаржевского в основании Днепропетровского университета и химического факультета, а

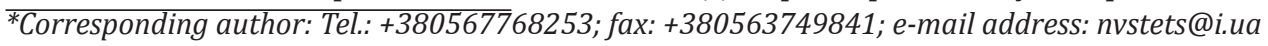

(C) 2014 Oles Honchar Dnipropetrovsk National University

doi: $10.15421 / 081403$ 
также организации учебного процесса в этом заведении.

Ключевые слова: Л. В. Писаржевский, электронная химия, теория катализа, Институт физической химии, Днепропетровский университет.

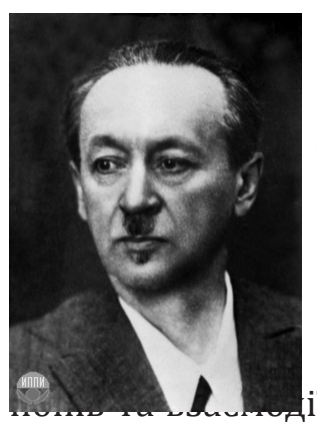

У лютому 2014 р. виповнилося 140 років із дня народження Лева Володимировича Писаржевського-основоположника електронної хімії. Він перший розглянув хімічний процес із урахуванням будови електронних оболонок атомів і ії між ними, сформулював загальновизнані нині уявлення про окисно-відновні реакції як процеси віддачі та приєднання електронів, заклав принципи електронної теорії каталізу та сольватної теорії електродного потенціалу. Л. В. Писаржевський відомий також як чудовий лектор і педагог. У своїх підручниках йому вдалося подати весь матеріал із хімії на основі електронних уявлень і таким чином реформувати викладання цієї науки.

Академік Л. В. Писаржевський був активним громадським діячем, визначним організатором науки, ініціатором створення Інституту фізичної хімії АН України - першого науково-дослідного закладу такого профілю в Українi, названого пізніше на честь вченого.

\section{Основні етапи життєвого шляху}

Академік Л. В. Писаржевський народився 13 (1 - за старим стилем) лютого 1874 р. у Кишиневі [1-4]. (У деяких джерелах, наприклад [5], вказано іншу дату народження - 1871 р.)

Батько, Володимир Ігнатович, походив із дворян, працював нотаріусом у м. Кишиневі. У 1878 р. він раптово помер. Через чотири роки мати, Ольга Лук'янівна, вирішила переїхати із сім'єю до Одеси до свого брата, який працював там архітектором.

В Одесі Лев став навчатися у Рішельєвській класичній гімназії (нині - ліцей). Матеріальне становище сім'ї було скрутним, що змусило Лева з 14 років заробляти на життя, даючи уроки.

Після закінчення гімназії у 1892 р. Лев Володимирович вступив до Новоросійського (нині Одеський) університету на природничо-медичний факультет [4]. Деякий час він вагався щодо обрання майбутньої спеціалізації між хімією та медициною. Його вподобання сформувалися під впливом професора П. Г. Мелікова (Мелікішвілі), який залучив допитливого студента до експериментальних досліджень з основної тематики кафедри - вивчення пе- роксидів та надкислот.

Коло наукових інтересів Лева Писаржевського в період навчання в університеті було досить широким. Тема його дипломної роботи належала до галузі органічної хімії, він виконував її під керівництвом П. І. Петренка-Крітченка.

По закінченні університету (1896) Л. В. Писаржевський залишився працювати в цьому ж закладі. У 1897 р. його призначили спочатку позаштатним, через рік - штатним лаборантом хімічної лабораторії, а згодом - асистентом.

Паралельно з викладацькою діяльністю в цей період Л. В. Писаржевський інтенсивно займався експериментально-дослідною роботою спочатку з П. Г. Меліковим, а потім і самостійно. За чотири роки він опубліковував у Росії та за кордоном близько 20 наукових праць у галузі вивчення пероксидів і надкислот. Завдяки цим дослідженням ім'я Л. В. Писаржевського стало відоме в науковому світі. Їх спільна 3 П. Г. Меліковим узагальнююча праця «Исследования над перекисями» була відзначена в 1899 р. найвищою нагородою Петербурзької (Російської) академії наук - Ломоносівською премією. Завершив дослідження в цьому напрямку Л. В. Писаржевський магістерською дисертацією «Перекиси и надкислоты», виданою в 1902 р. Ця робота містить масштабний експериментальний матеріал, методи й узагальнення, які й до сьогодні мають значну наукову цінність.

Д. І. Менделєєв процитував кілька робіт Л. В. Писаржевського в останніх виданнях «Основ хімії» і дав їм досить високу оцінку. Також він звернув увагу на значення цих робіт для «укріплення періодичного закону» [6].

У 1900 р. Л. В. Писаржевського як здібного та перспективного ученого відправили в зарубіжне відрядження у Фізико-хімічний інститут Лейпцизького університету (Німеччина). Цей університет був визнаним центром розвитку нової на той час галузі науки - фізичної хімії. Ним керував відомий учений-хімік В. Оствальд. У лабораторії інституту молодий науковець мав змогу спілкуватися з основоположниками фізичної хімії - Я. Вант-Гоффом, В. Нернстом, М. Боденштейном [2].

Працюючи з 1904 р. на посаді завідувача кафедри неорганічної хімії у Юр'євському (Тартуському) університеті, Лев Володимирович 
розпочав новий цикл досліджень щодо впливу розчинника на хімічну реакцію. Їх результати відображено в докторській дисертації «Свободная энергия химической реакции и растворитель». Особливий інтерес становлять дані щодо електропровідності і в'язкості неводних розчинів. Зазначимо, що Л. В. Писаржевський один із перших здійснив систематичні дослідження в галузі електрохімії неводних розчинів. Учений виявив кілька нових закономірностей, зокрема вивів і експериментально підтвердив правило про незалежність граничного значення добутку в'язкості на електропровідність від розчинника (1905). Це правило в літературі нерідко помилково приписували П. І. Вальдену.

Експериментальні дослідження щодо впливу розчинника на хімічні реакції вчений продовжив у Київському політехнічному інституті, до якого він перейшов у 1908 р. Київський період життя Л. В. Писаржевського тривав недовго у зв'язку з революційними подіями тих часів.

Після від'їзду з Києва наукова діяльність ученого перервалась на два роки. Проживаючи деякий час у Москві, він став одним із засновників (разом із професором В. О. Вагнером) та перших редакторів науково-популярного журналу «Природа», який виходить і до цього часу.

Найбільш плідний етап творчої діяльності Л. В. Писаржевського пов'язаний із Катеринославом (Дніпропетровськом). У 1913 р. Лев Володимирович прийняв запрошення Гірничого інституту в Катеринославі. Його було обрано ординарним професором кафедри загальної хімії. У той час Л. В. Писаржевський займався переважно прикладними питаннями, а саме виділенням йоду з морських водоростей за новим, розробленим разом із Н. А. Аверкієвим, способом [1], виробництвом спрощених протигазів тощо.

\section{Наукова та педагогічна діяльність ученого в Дніпропетровську}

Виконуючи прикладні роботи з оборонної тематики, Л. В. Писаржевський не припиняв, однак, теоретичних наукових досліджень. У цей період у нього вже остаточно сформувалися нові наукові інтереси. У 1914 р., читаючи для міського гуртка інженерів цикл лекцій «Фізична хімія та одне з ії основних завдань», Л. В. Писаржевський підійшов до розгляду ключових питань хімії з нових позицій синтезу електронної фізики та йонної хімії для пояснення хімічних процесів [3]. Із того часу й до кінця жит- тя питання про електрони в хімії залишалися для вченого пріоритетними [7].

Сьогодні загальновизнано, що хімічні реакції зумовлені переміщенням та взаємодіями електронів, а окисно-відновні процеси зводяться до переходу електронів від відновника до окисника. Тоді ж лише незначна кількість вчених розуміли це, і потрібна була неабияка наукова сміливість та інтуїція для висловлювання таких ідей. Уже в 1914 р. Л. В. Писаржевський на основі нових поглядів розвинув теорію гальванічного елемента, а починаючи 31922 р. застосовував електронні уявлення для пояснення каталітичних процесів. Цим він і займався останні 15-20 років творчої діяльності. Теорія каталізу тоді тільки починала розвиватися і дуже відставала від практичних потреб. Намагаючись поширити на гетерогенний каталіз свої електронні уявлення про сутність окисно-відновних хімічних перетворень, Л. В. Писаржевський запропонував електронну теорію каталізу на металах [8].

Дисоціація атомів металу на йони та електрони й існування вільних електронів у металі повинні, як вважав Л. В. Писаржевський, відобразитися на особливостях механізму каталітичної дії металів. Вільні електрони металу, на його думку, відіграють роль активаторів для молекул газу, що беруть участь у реакції. «Адсорбційні теорії не враховують специфічних особливостей груп каталізаторів, не кажучи вже про окремі каталізатори тієї чи іншої групи. А проте, бажаючи виявити механізм дії каталізатора тієї чи іншої групи, це треба враховувати в першу чергу.

<...>Я розглянув... групу металів - типових каталізаторів, і мені одразу кинулась у вічі та їхня особливість, що в них $є$ вільні електрони, заряди яких при їх великій рухливості, безумовно, повинні брати участь у явищах каталізу металами» (переклад наш) [8].

На противагу поширеним тоді спрощеним уявленням про гетерогенний каталіз як суто адсорбційне явище Л. В. Писаржевський у ряді робіт вказував, що каталітична дія твердих каталізаторів, які мають електронну провідність, є наслідком збудження реагуючих атомів та молекул електронами кристалічної решітки каталізатора.

Притаманна Л. В. Писаржевському переконаність у тому, що всі наукові досягнення мають бути загальним надбанням і в лекціях повинні відображатися сучасні хімічні теоpiї, надихала його на боротьбу за утвердження електронних поглядів у хімії, відповідну пере- 
будову викладання. Вчений розумів, що без істотного перегляду навчальних планів і вдосконалення підручників не могло бути й мови про підготовку нової генерації хіміків, здатних проводити дослідження на сучасному рівні. Розроблені під керівництвом Лева Володимировича навчальні плани для хіміків Дніпропетровського університету були рекомендовані Наркомосвіти України для хімічних факультетів усіх університетів [9].

Л.В. Писаржевський уперше ввів у практику навчального процесу електронне трактування окисно-відновних процесів, теорії рівноважних електродних потенціалів.

У 1926 р. вийшов друком підручник Л. В. Писаржевського «Введение в химию (на основе строения атома и электронно-ионного строения молекул)», у якому весь матеріал було викладено з позицій електронної хімії. (3 1930 р., коли співавтором Л. В. Писаржевського стала М. А. Розенберг, підручник став називатися «Неорганическая химия».) У виданні велику увагу приділено вивченню періодичного закону, наведено порівняльні електронні характеристики елементів за групами періодичної системи, викладено основні положення електронної теорії каталізу, для пояснення сутності хімічних перетворень широко застосовано поняття термодинаміки [10].

Л. В. Писаржевський постійно вдосконалював, редагував, доповнював свій підручник, було здійснено кілька його перевидань (останнє - у 1934 р. [10]), ним послуговувалися не лише студенти, а й аспіранти та науковці. Тривалий час цей підручник, який можна назвати класикою електронної хімії, був унікальним не тільки для нашої країни, а й для зарубіжжя. Лише в 30-ті роки XX ст. у Німеччині з'явився відомий підручник Г. Ремі, написаний зі схожих позицій.

Л. В. Писаржевський вдало поєднував науковий і педагогічний процеси. Фактами нових відкриттів (у тому числі й своїх) він поповнював і модернізував курс лекцій, який читав. У той же час, готуючись до лекцій, він уточнював деякі теоретичні положення, перевіряв їх експериментально.

Завдяки зусиллям і праці Л.В.Писаржевського Катеринослав поступово став одним із наукових центрів країни. Навколо вченого згуртувався значний колектив співробітників-однодумців, для якого в 1922 р. при Гірничому інституті було створено науково-дослідну кафедру електронної хімії. Кафедра стрімко розвивалася, поширювала свою діяльність і на суміжні галузі теоретичної хімії та фізики. У 1927 р. на основі цієї кафедри з ініціативи Л. В. Писаржевського було створено Український інститут фізичної хімії, один із перших науково-дослідних закладів цього профілю в країні. До складу інституту в перші роки його існування входило чотири відділи: електронної хімії, електрохімії розчинів, фізичної хімії органічних сполук і фізичних вимірів [11]. У 1934 р. інститут перейшов із підпорядкування Народного комісаріату освіти до системи Академії наук УРСР, а 1938 р. йому присвоїли ім'я засновника і незмінного керівника - Л. В. Писаржевського. Досить швидко інститут фізичної хімії став одним із провідних наукових центрів Радянського Союзу.

У 1925 р. професора Л. В. Писаржевського обрано дійсним членом Академії наук УРСР, через два роки - членом-кореспондентом, а в 1930 р. - дійсним членом Академії наук СРСР. Того ж року йому присуджено найавторитетнішу премію СРСР - імені В. І. Леніна.

Одночасно $з$ інтенсивною організаційною та науковою діяльністю Л. В. Писаржевський активно займався громадською роботою: 1929 р. його обрано кандидатом у члени Центрального виконавчого комітету (ЦВК) СРСР, а наступного року - членом ЦВК Української та Грузинської РСР [3; 4].

\section{Організаційна діяльність \\ Л. В. Писаржевського в Дніпропетровському університеті}

На момент переїзду Л. В. Писаржевського до Катеринослава це місто ще не мало статусу університетського. У ньому існувало лише два інститути - Гірничий та Учительський (останній - з трирічним терміном навчання). Однак Катериностав уже став важливим промисловим центром Півдня Росії, тому потреба у фахівцях із університетською освітою була досить гостра. Громадськість міста неодноразово зверталась до уряду країни із клопотанням про відкриття університету [12], проте його організацію через ряд різних причин постійно відкладали.

У травні 1913 р. відбулися збори ініціативної групи професорів та викладачів Гірничого інституту, на яких було висунуто ідею відкриття в Катеринославі вищих жіночих курсів. До складу ініціативної групи входив і новий професор інституту Л. В. Писаржевський. Цю пропозицію зрештою підтримала влада, і влітку 1916 р. вищі жіночі курси було створено в складі двох факультетів - медичного та фізи- 
ко-математичного. При цьому було обумовлено, що викладання здійснюватиметься за університетською програмою [12].

Створенням курсів проблему вищої освіти в місті було вирішено лише частково. Наукова громадськість Катеринослава продовжувала наполегливо добиватися відкриття університету. Л. В. Писаржевський, зокрема, у 1918 р. звернувся з листом до особи, наближеної до урядових кіл, з проханням посприяти створенню в місті університету [12].

У серпні 1918 р. статут університету було затверджено і направлено до Катеринослава. Склалося так, що університет відкрили як платний приватний навчальний заклад із російською мовою викладання. Проте вже в січні 1919 р., зі встановленням в Україні радянської влади, Катеринославський уніве-рситет набув статусу державного закладу [12].

Л. В. Писаржевский, продовжуючи працювати професором Гірничого інституту, завідував в університеті кафедрою неорганічної хімії (сумісництво було тоді поширеним явищем), а після від'їзду в 1921 р. до Харкова професора Г. Ю. Тимофєєва деякий час очолював також і кафедри фізичної та аналітичної хімії $[2 ; 13$; 14].

Під час роботи на вищих жіночих курсах Л. В. Писаржевський познайомився з молодою асистенткою із Медичного інституту Мальвіною Ассирівною Розенберг. Знайомство досить швидко переросло в глибокі почуття, які підтримувались єдністю поглядів та наукових інтересів. Мальвіна Ассирівна залишалась вірним другом і соратником Лева Володимировича до останніх днів його життя, хоча офіційно їх сімейні стосунки так і не були оформлені.

На початку 20-х років XX ст., після закінчення громадянської війни, коли країна стала поступово розвивати економіку, відчувалася гостра потреба в інженерно-технічних та педагогічних кадрах. Для вирішення цієї проблеми керівництво Наркомосвіти України постановило відкрити ряд інститутів педагогічного та інженерно-технічного профілю, ліквідувавши при цьому всі університети [2; 12]. (Як з'ясувалося пізніше, таке рішення було недалекоглядним.)

Восени 1920 р. на базі фізико-математичного факультету університету було створено Інститут теоретичних наук (ITEH), який мав чотири відділення: фізико-математичне, хімічне, біологічне та геолого-географічне. Головою ради ITEН (фактично ректором) обрали Л. В. Писаржевського, а його заступником - ві- домого вченого-біолога Д. О. Свіренка. Однак уже влітку 1921 р. вийшла постанова про злиття ITEН зі створеним незадовго до цього Інститутом народної освіти (IHO). На базі двох закладів було організовано Катеринославський вищий інститут народної освіти (КВIHO), i Л. В. Писаржевський залишив посаду ректора.

Діяльність інституту народної освіти спрямовувалася переважно на підготовку вчителів, і умови для проведення науково-дослідних робіт були обмеженими. Але учені та викладачі КВІНО намагалися підтримати університетський дух та стиль діяльності навіть за таких обставин. Вони почали організовувати студентські наукові гуртки, які традиційно існували в університетах Росії, і стали на шлях підготовки майбутніх учених через систему таких гуртків. Хімічний науковий гурток заснували в 1924 р. Ним керували професор Л. В. Писаржевський, недавній випускник КВІНО С. 3. Рогінський, студенти В. А. Ройтер, К. С. Ляліков та ін. Діяльність таких гуртків була досить активною, із доповідями виступали як викладачі, так і студенти. Це була хороша школа для майбутніх наукових працівників.

Хімічне відділення КВІНО та кафедри хімічного профілю в 20-ті роки знаходились у навчальному корпусі № 2 (зараз просп. К. Маркса, буд. 36) і не мали своєї лабораторної бази. Тому лабораторні заняття проводились переважно в Гірничому інституті, насамперед на кафедрі Л.В.Писаржевського. У 1930 р. було відбудовано корпус № 3 (просп. К. Маркса, буд.35), у приміщеннях якого розмістили хімічне відділення (незабаром воно стало факультетом). Реконструкція корпусу відбувалась за безпосередньої участі Л. В. Писаржевського [13]. Крім навчальних лабораторій у корпусі містились дві лекційні аудиторії, побудовані амфітеатром. В одній із них (№ 17) читав лекції професор Л. В. Писаржевський.

У 1927 р. Л. В. Писаржевського призначили директором Українського науково-дослідного інституту фізичної хімії. Із того часу наукова діяльність ученого зосередилась у цьому закладі. Тому з другої половини 20 -х років він не обіймав в IHO офіційних адміністративних посад (керівництво кафедрою неорганічної хімії, наприклад, він передав своєму найближчому соратнику та послідовнику М. А. Розенберг), але продовжував брати участь у роботі хімічного відділення. Тематика наукових досліджень хімічних кафедр у 20-30-ті роки так чи інакше була пов'язана з розвитком напрямів, розпочатих академіком Л. В. Писаржевським [9; 13; 
14]. Його наукові та педагогічні ідеї знайшли продовження в працях М. А. Розенберг, Ф. І. Березовської, А. М. Занько, О. I. Бродського (усі вони завідували кафедрами на хімічному відділенні), а також К. С. Лялікова, М. С. Бєлєнького, М. Я. Рубаника, О. С. Афанасьєва, В. А. Ройтера, С. А. Гусинської, М. С. Ашкіназі та ін. [1; 15]. Багато з них згодом стали професорами, докторами наук, а О. І. Бродський та В. А. Ройтер академіками.

На початку 30-х років в Україні постала необхідність поновлення університетської освіти. Дніпропетровське обласне бюро союзу наукових працівників відповідно до постанови ВУЦВК від 10 березня 1933 р. створило комітет сприяння організації університету. Очолити комітет, до складу якого ввійшли академік О. М. Динник, професори В. С. Фінкельштейн, Л. В. Рейнгард та інші, було доручено Л. В. Писаржевському [12]. Проблем, пов'язаних зі створенням університету, виявилось багато. Однак уже 1 жовтня 1933 р. відновлений Дніпропетровський університет розпочав навчальну і наукову діяльність у складі шести факультетів, серед них значився і хімічний, у діяльності якого Л. В. Писаржевський продовжував брати безпосередню участь до кінця свого життя.

Помер академік Л. В. Писаржевський 23 березня 1938 р. у Дніпропетровську після тяжкої та тривалої хвороби, пов'язаної із туберкульозом легень. Поховано вченого в Дніпропетровську, у парку, названому його іменем. На його могилі встановлено пам'ятник роботи відомого скульптора М. Г. Манізера.

Сподіваємося, що життя та багатогранна діяльність, невичерпна енергія та риси особистості академіка Л. В. Писаржевського стануть яскравим взірцем для молоді.

\section{Бібліографічні посилання}

1. Бродский А. И. Лев Владимирович Писаржевский / А. И. Бродский // Люди русской науки.М.: Госфизматиздат, 1961. - Т.1. - С.574-584.

2. Коваленко В. С. Академік Лев Володимирович Писаржевський: монографія. Серія «Видатні постаті університету» / В. С. Коваленко, В. Ф. Варгалюк, Н. В. Стець. - Д.: Вид-во ДНУ, 2013. - 112 с.

3. Лев Володимирович Писаржевський (18741938). Матеріали про життя і творчість. - К.: Вид-во АН УРСР, 1940. - 156 с.

4. Яцимирський К. Б. Лев Володимирович Писаржевський / К. Б. Яцимирський, Р. А. Кострова. К.: Наук. думка, 1975. - 79 с.

5. Кузьменко С. І. До біографії Л. В. Писаржевського / С. I. Кузьменко // Держ. арх. Дніпропетр. обл. - Ф. Р680, оп. 1, спр. 40, арк 2.
6. Менделеев Д. И. Основы химии / Д. И. Менделеев. - 13-е изд. - М.; Л.: Научтеххимиздат, 1947. - Т.2. -708 с.

7. Писаржевский Л. В. Электрон в химии: избранные труды /Л. В. Писаржевский. - К.: Изд-во АН УССР, 1956. - $191 \mathrm{c.}$

8. Писаржевский Л. В. Избранные труды в области катализа /Л. В. Писаржевский. - К.: Изд-во АН УССР, 1955. - $152 \mathrm{c}$.

9. Березовская Ф. И. Химический факультет Днепропетровского Государственного университета - школа академика Л. В. Писаржевского / Ф. И. Березовская// Творческий путь академика Льва Владимировича Писаржевского. - Х.; 1935. - С. 17-19.

10. Писаржевский Л. В. Неорганическая химия /Л. В. Писаржевский, М. А. Розенберг. - Х.; К.: Госнаучтехиздат Украины, 1934. - 564 с.

11. Пісаржевський Л. В. Історія розвитку катедри та заснування інституту / Л. В. Пісаржевський // Вісті Укр. наук.-дослід. ін-ту фіз. хімії. - 1929. T. 2. - С. 1-9.

12. Історія Дніпропетровського національного університету / гол. ред. кол. М. В. Поляков. - Д.: Вид-во Дніпропетр. ун-ту, 2003. - 232 с.

13. Коваленко В. С. Історія хімічного факультету Дніпропетровського національного університету (наукові напрями, події, люди) / В. С. Коваленко, Ф. О. Чмиленко, В. Ф. Варгалюк. - Д.: Видво Дніпропетр. ун-ту, 2011. - 192 с.

14. Тридцать лет химическому факультету / М. А. Розенберг, Ф. И. Березовская, О. К. Скарре и др. // Материалы к истории ДГУ. - Д., - КП 165, apx. 273.

15. Научная работа химического факультета. - Д., Музей історії ДНУ. - КП 179, арх. 269.

\section{References}

1. Brodskyj, A. I. Lev Vladimirovich Pisarchevskyj, Lyudy russkoy nauky. Moskow: Gosfizmatizdat, vol. 1, 1961, P. 574-584. [in Russian]

2. Kovalenko, V. S., Vargaljuk, V. F., Stets, N. V. Akademik Lev Volodymyrovych Pysarzhevskyy: monohrafiya. Seriya «Vydatni postati universytetu». Dnípropetrovs'k: Dnepropetrovsk University Publishing House, 2013, 112 p. [in Ukrainian]

3. Lev Volodymyrovych Pysarzhevskyy (1874-1938). Materialy pro zhyttya i tvorchist. Kiev: Vid-vo AN URSR, 1940, 156 p. [in Ukrainian]

4. Yacymyrskyj, K. B., Kostrova, R. A. Lev Volodymyrovych Pysarzhevskyy. Kiev: Nauk. dumka 1975, 79 p. [in Ukrainian]

5. Kuzmenko, S. I. Do biohrafiyi L. V. Pysarzhevskoho, The State Archives of the Dnepropetrovsk region, F. R680, l. 1, f. 40, s. 2. [in Ukrainian]

6. Mendeleev, D. I. Osnovyi himii. Moscow; Leningrad: Nauchtehhimizdat, vol. 2, 1947, 708 p. [in Russian]

7. Pysarzhevskyj, L. V. Elektron v himii: izbrannyie trudyi. Kiev: Izd-vo AN USSR, 1956, 191 p. [in Russian] 
8. Pysarzhevskyj, L. V. Izbrannyie trudyi v oblasti kataliza. Kiev: Izd-vo AN USSR, 1955, 152 p. [in Russian]

9. Berezovskaya, F. I. A chemical faculty of the Dnepropetrovsk State university is school of academician L. V. Pysarzhevskyj, Tvorcheskyy put akademyka Lva Vladymyrovycha Pysarzhevskoho. Kharkov; Dnepropetrovsk, 1935, P.17-19. [in Russian]

10. Pysarzhevskyj, L. V., Rozenberg, M. A. Neorhanycheskaya khymyya. Kharkov; Kiev: Hosnauchtehyzdat Ukrayny, 1934, 564 p. [in Russian]

11. Pysarzhevskyj, L. V. History of development of department and founding of institute. Visti Ukrayinskoho naukovo-doslidchoho instytutu fizychnoyi khimiyi, 1929, vol. 2, p. 1-9. [in Ukrainian]

12. Istoriya Dnipropetrovskoho natsionalnoho uni- versytetu, edited by N. V. Polyakov. Dnipropetrovsk: Dnepropetrovsk University Publishing House, 2003, 232 p. [in Ukrainian]

13. Kovalenko, V. S., Chmylenko, F. A., Vargaljuk, V. F. Istoriya khimichnoho fakultetu Dnipropetrovskoho natsionalnoho universytetu (naukovi napryamy, podiyi, lyudy). Dnipropetrovsk: Dnepropetrovsk University Publishing House, 2011, 192 p. [in Ukrainian]

14. Rozenberg, M. A., Berezovskaya, F. I., Skarre, O. K. There are thirty years to the chemical faculty, Materials to history of DSU. Museum of history of DSU, KP 165, f. 273. [in Russian]

15. Nauchnaya rabota khymycheskoho fakulteta. Museum of history of DSU, KP 179, f. 269. [in Russian] 